\title{
The Dynamics of Traditional and Contemporary Angklung Development as a Tourist Attraction Based on Social Creativity in Saung Angklung Udjo
}

\author{
Budiman Mahmud Musthofa* \\ Tourism Study Program, Vocational Education Program,Universitas Indonesia \\ *Email: b.mahmud@ui.ac.id
}

\begin{abstract}
Social creativity is one of the main keys to the continuity and sustainability of creative tourist attraction developments. The sustainability of social creativity occurs when the community is directly involved as active participants in the creative activities and also economically benefits. This study reports on the results from qualitative research that examined the dynamics of the traditional and contemporary angklung socially creative tourist attractions in Saung Angklung Udjo (SAU), Bandung, West Java. The dynamics of the angklung traditional to contemporary development were found to be caused by the continual shared individual creativity to social creativity processes that allowed the local people to benefit from the resulting product. The development of the creative tourism attractions in SAU was also a response to the spirit of the changing times that meant that the angklung attractions were attracting significant attention. The authors hope that the SAU creative attraction development process based on social creativity can be a creative tourism model across Indonesia.
\end{abstract}

Keywords: social creativity, creative tourism, angklung, Saung Angklung Udjo

\section{Introduction}

National tourism and global tourism are the leading national economic development business sectors. The World Tourism Agency (UN-WTO) reported that in 2017, there were 1.322 billion international tourist movements, with global tourism revenues reaching US\$5.3 trillion, and predicted that the 2018 growth would result in global tourism revenues of around US\$5.6 trillion. The World Bank also reported that the world tourism revenue was expected to grow by $6.7 \%$ in 2018, which was much higher than the predicted 2018 global GDP growth rate of $3.1 \%$. The tourism foreign exchange sector in 2017 was US $\$ 16.8$ billion, which was a significant increase compared with 2016 (http://indonesiatouristnews.com/ Global Tourism Continues to Grow 2018, Total 1.322 Billion Tourists Throughout the Year 2017/).

The increase in global tourism development has meant that tourism has become a strategic area for income generation, job creation, business development, and the mobilization of socioeconomic community activities. Therefore, there are significant opportunities for the tourism industry in Indonesia to continue to creatively develop as a destination and to fulfill the growing demands for creative tourism, which is now being seen as a new tourism area. Previously, people were attracted to Indonesia for coastal tourism and cultural tourism. However, creative tourism involves greater interactions so that the tourists can have educational, emotional, social, and participatory interactions with a place, a living culture, and the people (Dewatmoko, 2016).

The creative tourism sector has been rapidly growing (Jelinčić, 2017) possibly due to the rise in creative industries. Consequently, there has been an increased research focus on creative tourism in terms of the experiences, involvements, and added tourism development value (De Bruin,2016). As in the rest of the world, in Indonesia, the creative tourism recognition is relatively new. Richards and Raymond defined creative tourism as one that offers visitors the opportunity to develop their creative potential through active participation (Richards, 2000; Richards, 2009).

Creative tourism as defined by Richard has been in Indonesia for decades. One creative tourism experience that was developed more than 50 years ago and continues to grow is Saung Angklung Udjo (SAU). SAU is a creative tourism destination founded by Udjo Ngalagena to allow visitors to become creatively involved in a traditional social community culture, which has made SAU a well-known creative tourism destination. 
Therefore, the study of creativity, social creativity, and creative tourism in Indonesia is essential as this country has a wide variety of potentially creative resources that could be harnessed to improve the welfare of the community. This study analyzed the traditional to contemporary-based social creativity dynamics of the angklung developments in SAU.

\section{Literature Review}

Creativity is defined as a general ability to create something new, to provide new ideas that can be applied to problem-solving, and to determine new relationships between preexisting elements (Munandar, 2009; Munandar, 2012). Therefore, creativity does not necessarily involve creating something new but could be a reimagining of something that had been there before (Munandar, 2012; Semiawan, 2009). An individual's creativity is inextricably linked to the creator's culture and the society in which they live (Soemardjan, 1983). Ember explained that new creations are influenced by the sociocultural conditions of the creator's society and that the relationship between the individual and their culture allows for further creative developments (Ember, 1996).

Creativity evolves through a series of social interactions. As individuals with creative potential are influenced by their sociocultural environment, the individuals and their communities are ever-changing; that is, creativity is an individual and a collective sociocultural act, which is in line with the sociopsychological assumption that the actualization of creativity is the result of the interactions between psychological factors (internal) and the environment (external) (Supriadi, 1994).

These assumptions reinforce that creativity is closely related to the social dimension, which was especially true in early human consciousness developments. The social nature of ancient creative human activities (storytelling, music, dancing, and rituals) has been recorded in cave and rock paintings and also signifies the importance of art as an expression of aggregation and/or social gathering. From a social point of view, creativity can be interpreted as a functional and dialogical relationship between the people, the tasks that exist in certain environments, and the particular sociohistorical framework (Reilly, 2004). Creative activities grow out of the relationships between individuals and their work and from the interactions between individuals. In other words, creativity occurs because of the interactions in an individual's mind and their sociocultural context (Fischer, 2011), that is, dialogical interactions in a relational context. These types of oriented creative processes are present in SAU's focus on learning, playing, art, performing, and making angklung as social action.

Creativity enables people to think collectively about the innovation process. If social life is regarded as a network of interactions, at the "micro" or "macro" level, between individuals and society, it is conceivable that the innovations that occur in turn form the spatial coordinates of a social system (Domingues, 2010). An example of a creative activity that occurs collectively was revealed in a study of a North American jazz group in which it was found that the dynamics of the individuals, group members, and the musical environment gave birth to creative musical development and that the collaboration and combination from the individual player and group capabilities within the Jazz group produced unique and exciting combinations (Watson, 2007).

Creativity occurs in the relationships between individuals and society and between individuals and their technical environment. Individual and community creativity can be integrated using appropriate collaborative models, which Fischer referred to as "sharing of products of individual creativity" (Fischer, 2011) to explain that the sharing of products arising from individual creativity allows others to work on the same thing as an ongoing activity without repeating the work done by the predecessor. For example, the open-source movement suggests that the development of open-source coding systems has allowed for further developments. Therefore, the spread of individually created products allows others to work and contribute to the sustainable activity.

One of the keys to creative sustainability is the culture of participation (Fischer, 2011), which has been reinforced by studies into social creativity in which powers of participation and learning, social creativity, and culture have been exploited (Fischer, 2014). This study found that creativity could be social, which gave rise to the term "social creativity," that is, a culture of participation that is supported by a socio-technical environment in which all stakeholders are able to express themselves to generate new insights from the combination of different perspectives.

The study of community creativity was the focus of a study titled Building Creative Communities: The Role of Art and Culture. Art and culture can enhance economic development by developing creative communities, which are communities that harness the advantages of the essential relationships among art, culture, and business (Eger, 2006). Several studies have been conducted on creativity and tourism, some of which were studies on cultural and creativity-based tourism strategies (Hermantoro, 2011; Richards, 2011). Studies on creative tourism in Taiwan found that there was an increasing trend to develop creative tourism products and 
services that included local culture and traditional arts to enhance tourist experiences (Chang, 2014). Another study on creative tourism in Cape Town (South Africa) found that because the creative tourism market was still small, there were only small innovations and a lack of integration; however, it was concluded that the market potential was enormous (Booyens, 2015).

Creative tourism generally involves activities that are related to authentic tourist participation and experiences that allow for the development of creative potential and skills through contact with local people and community cultures (Richards, 2009), which can also be equated with UNESCO's creative motoring concept; "Creative tourism as travel directed toward an engaged and authentic experience, heritage, or special character of a place, and that creates a connection to the residents and their culture" (UNESCO, 2006).

The Ministry of Tourism has placed restrictions on authentic creative tourist experiences that can be perceived by tourists, claiming that such experiences should be participative and interactive and involve informal rather than mass learning that is closely related to the local community (Kementerian kebudayaan dan pariwisata, 2010). Compared with passive tourism, creative tourism allows visitors to be more actively involved in the local attractions (Hermantoro, 2011).

\section{Methods}

This study used a qualitative case study approach, with the focus being on SAU. Qualitative research explores social or humanitarian problems with the aim of understanding the meaning being ascribed by individuals or groups of people (Creswell, 2010). This study was explanatory in nature with the main aims being to explain the reasons for the occurrence of events and to shape, deepen, and develop associated theories (Neuman, 2013). This research was conducted at SAU, Jalan Padasuka No 118, Bandung, West Java, with the informants being selected using purposive sampling. The primary data were obtained from observation and interviews with informants, such as families, artisans, students, players, trainers, and community leaders. The secondary data were obtained from a literature review of relevant documents, journals, articles, and other materials.

\section{Results and Discussion}

\section{a. Udjo Ngalagena as Creative Person}

The role of creative figures is very important when developing tourist attractions. In SAU, the main character was the founder, Udjo Ngalagena, who has been developing art with his family for over 50 years that has received, supported, and followed by the community. Udjo was very aware that his creativity would be easily accepted and supported by the community if his creations were in line with the traditions of the society. Therefore, since the establishment of the SAU program in 1966, the development of Saung Angklung Udjo has been focused on three main activities: education, production, and angklung Sundanese cultural performances.

At SAU, a range of Sundanese traditional art is produced, packaged, and preserved, and performances that are associated with the angklung training and education are created. SAU, which was originally established in 1968 because of Udjo Ngalagena's love for Sundanese art and especially for the education and preservation of angklung, has developed into a cultural and creative tourism destination without abandoning its original purpose of preserving Sundanese culture. SAU developed professionally by making traditional art a tourist attraction, which has consequently developed into a cultural tourism destination based on a creative association with the community.

The success of SAU cannot be separated from Udjo Ngalagena being a powerful creative figure in the field of traditional art and the significant influence his monumental works at SAU have had on the surrounding community; therefore, he is highly admired by the community (Furchan, 2005). As a key heralder for Sundanese art and culture, Udjo's creativity cannot be separated from the influence of his social environment, which has associated his creativity with his immediate social realm; that is, as explained by Ember (1996), he is a character whose creation process is influenced by the social conditions in his society.

All informants for this research commented that Udjo's creative genius can be seen in the development of the performances, which attract packed audiences. Udjo develops his shows to attract the interests of many people by creatively including such aspects as common children's games. His uniqueness and genius take something that others see as ordinary and incorporates them into a culturally interesting show. 
Udjo's creativity has popularized hand signing for SAU Angklung learning to replace beam and number notations. Actually, these hand signs were initially taught to him by an art teacher from the Netherlands when he was at school; however, he later developed this technique, taught it to the trainers, and included it in the performances so that the audience/tourists can quickly learn to play the angklung, which keeps them involved in playing the angklung throughout the performance.

The hand sign method has become SAU's specialty since 1970. An internal SAU survey showed that the tourists were very impressed with these sessions. Therefore, in line with the creative tourism definitions (Richards, 2000; Richards, 2009; UNESCO, 2006), SAU has been practicing creative tourism for some time. SAU's initial focus on production and training has evolved over time to become a growing tourist destination that has had significant sociocultural and economic impacts.

\section{b. Social Creativity and the Dynamics of Angklung Development}

As creativity has limitations, it needs to be done jointly. Recognizing his limitations, Udjo Ngalagena has developed SAU to involve extensive collaboration, which means that the creative activities in SAU have grown into a relationship between the individuals and the society, which further reinforces the social creativity concept that creativity involves interactions between an individual and their sociocultural context (Fischer, 2011). Therefore, the creative activities associated with the mind of the Udjo exist in the dialogical relational interactions between Udjo and his society. This type of relation-oriented creative process can be seen in SAU in, for example, the process of learning, playing, art, performance, and making angklung.

At the SAU, almost all performers are local people, many of whom have been participating since 1963. Therefore, social creativity can lead to significant progress and prosperity in the surrounding community. Udjo has managed to transfer his knowledge and creativity to the community through shared creativity, that is, by transforming the creativity from a personal creativity to collective creativity to social creativity. From the data collected in the field-related activities, shared creativity is the ability of the creative individuals to share their creativity with others, which then leads to social creativity.

Udjo's focus on community interactions has given rise to creative new attractions, such as improvisation in the creation of SAU performances and performance materials; Ujang Burhan's work with bamboo musical instruments; a Sundanese artist who popularized Arumba (Bamboo Music); modifications to the traditional art forms of wayang golek, ceremony helaran; the mask dance and peacock dance; and the creation of various angklung, such as the angklung mini.

Udjo and his successors have collaborated with the local community to produce their innovations; angklung toel, grand angklung, angklung in android applications, angklung robot, and various other educational methods, performances, and angklung productions. These types of collaborative developments are in line with the innovation concepts proposed by Owlia (2008), who claimed that joint innovations provide added value and in particular bring value and benefit to the society.

These collaborative creative activities have ensured that because the local community closely follows Udjo's innovations, the angklung-related activities have become more festive and productive. Ultimately, the sustainability of SAU creativity requires active contributors who act as both active actors and users of the product. Sustainability, therefore, is ensured by allowing the community to be active contributors to the creative process. Consequently, as this collaborative creativity has been successfully exploited by the manager, SAU has become internationally recognized, which in turn has had a significantly positive economic impact on the community (Musthofa, 2017).

Udjo's ability to package and create angklung using collaborative, creative development could be a model that could be replicated successfully in other parts of Indonesia. The creative development across the generations can be seen in the development of the angklung group, Daeng Oktaviandi, which was first started by the Udjo boys. Similar to Udjo's developments, in 1985, Daeng Oktaviandi created his group to have a wider, more varied content, to include specific performance materials and bamboo musical instruments, and to have an education and development focus.

Udjo's angklung creativity development model for education, production, and performance was also successfully modified by Daeng Udjo, who sought to develop angklung performances based on more modern music. His group has received a positive response from the community, especially from the younger generation. The group developed into studio angklung Daeng Udjo, which was formally established on September 9, 1999, and has since grown larger. Even though studio angklung Daeng Udjo's focus is more modern, their education and learning methods are similar to those of Udjo Ngalagena.

Some of the key achievements have been in the training of hundreds of angklung artists and angklung orchestra performances at home and abroad; for example, on June 9, 2011, in Washington DC, a world record angklung playing record was set involving 5000 people; there have been angklung performances in China; and 
in 2015, after Sanggar Angklung Daeng Udjo joined SAU, 20000 people played the angklung together in Sabuga field in 2015, again breaking a record. In 1985, Udjo Ngalagena had led an angklung show to commemorate the 30th anniversary of the KAA, and in 2015, Son Udjo, and Daeng Oktaviandi assisted by some of the other Udjo sons, led a mass angklung show in Bandung to commemorate the 60th anniversary of the KAA.

The success of the Sanggar Angklung Daeng Udjo clearly indicates that Udjo has succeeded in developing a sound creative education model within a public space that can be channeled into next-generation creativity. The public space opens opportunities for families and the wider community to be creative to ensure sustainability and continuity and at the same time develop creative collaboration with other parties outside the community. One of Udjo's repeated messages is to keep the old and create the new, which had become representative of the spirit of SAU to ensure continual creativity.

The development of the creative tourism potential of SAU can also be seen as part of the new era of the Internet of things. Currently, the tourism industry uses information technology to obtain information on almost all tourism transactions, market structures, and customer needs in a single electronic platform, with the number of Internet users projected to increase globally by 51.5\% in 2019 (Babu, 2016). However, the Internet of things can also lead to a further flourishing of creative tourism, which SAU and Udjo have also considered very carefully. SAU has already developed an information technology-based strategy by opening a website (http://www.angklung-udjo.co.id) to provide information and developing YouTube videos to showcase SAU's performances and achievements.

SAU also seeks to cooperate with various parties to encourage an interest in angklung for the current generation. SAU developed an angklung game application in November 2011, iAngkung, which had been developed for iPhone, iPod, and iPadr by Dhany Irfansyah and Yulis Wibowo, to introduce angklung to the younger generations, and in 2012, SAU held an interactive event at which the audience could play digital angklung by shaking their iPad or iPhone to the right and left or swiping angklung images on the screen (http://bandung.bisnis.com/read/20120317/12/157872/seru-ramai-ramai-bermain-angklung-dengan-iphone-disaung-udjo (17/03/2012)). SAU has since also developed an angklung application for Android that can be downloaded and played (Daeanza, 2017).

SAU, therefore, continues to focus on new creative ways to attract audiences without forsaking their traditional values and continues to provide creative immersive experiences for the tourists who visit SAU. The many creative activities developed and conducted by SAU show that Angklung has been successfully developed as a traditional and contemporary tourist attraction and are strong examples of the types of tourism experiences that can be achieved through social creativity. However, the success of SAU also reveals that continued creative tourism requires managers to be constantly challenged when designing future creative tourism experiences. This study highlighted that the SAU managers were able to successfully harness social creativity and develop a participatory culture to provide "authentic" Sundanese culture and art tourist experiences that also allow tourists to develop their creative potential.

\section{Conclusion}

Udjo Ngalagena has been engaged in social Sundanese creative art activities for many years and has been successful in developing SAU as a creative tourist attraction, the products from which provide economic, social, and cultural added value that has sustained the local community for more than 50 years.

SAU's strong focus on social creativity and its utilization of information technology has also had a significant impact on angklung development in terms of its physical form, the development of performance materials, collaborations with other musical instruments, the development of souvenirs, angklung education, and the development of national and international networks, all of which has enabled SAU to grow and rapidly develop as a creative tourism destination. The creative tourism development model by the SAU is expected to be a template for the development of other tourist destinations and attractions that seek to make creativity and social creativity their main foci.

\section{Acknowledgment}

Thank are given to the large family of Udjo Ngalagena, who provided much of the information and data related to this study. 


\section{References}

Babu, S. R., \& Subramoniam, S. (2016). Tourism management in internet of things era. Journal of Information Technology and Economic Development, 7(1), 1-14. $\quad$ Retrieved from https://search.proquest.com/docview/1862029335?accountid=17242

Booyens, I., \& Rogerson, C. M. (2015). Creative tourism in Cape town: An innovation perspective. Dordrecht, The Netherlands: Springer Science and Business Media

Chang, L., Backman, K., \& Chih Huang, Y. (2014). Creative tourism: A preliminary examination of creative tourists' motivation, experience, perceived value and revisit intention. International Journal of Culture, Tourism and Hospitality Research, 8(4), 401-419, ISSN 1750-6182. doi: 10.1108/IJCTHR-04-2014-0032.

Creswell, J. W. (2010). Research Design Pendekatan Kualitatif, Kuantitatif, dan Mixed. Yogyakarta, Indonesia: Pustaka Pelajar

Daeanza, D. M., Nurhayati, O. D., \& Eridani, D. (Styczeń 2017). ISSN 2338-0403. Retrieved from https://jtsiskom.undip.ac.id/index.php/jtsiskom/article/view/12861. Aplikasi simulasi dan main angklung (Saung) berbasis android. Jurnal Teknologi dan Sistem Komputer, [S.1.], 5(1), 37-42. doi: 10.14710/jtsiskom.5.1.2017.37-42.

De Bruin, A., \& Jelinčić, D. A. (2016). Toward extending creative tourism: participatory experience tourism. Tourism Review, 71(1), 57-66. doi: 10.1108/TR-05-2015-0018

Dewatmoko, S. (2016). Creative Economy Based on Opportunity and Unique Competency on Business Strategy of Tourism Business in west Java. Academy of Strategic Management Journal: Jordan Whitney Enterprises, Inc., 15, Special Issue 3

Domingues, J. M. (2000). 'Social Creativity, Collective Subjectivity and Contemporary Modernity', Houndmills, Basingstoke, Hampshire RG21 6XS and London: Macmillan press Ltd.

Eger, J. M. (2006). Building creative communities: The role of art and culture. Futurist Journal, 18-22.

Ember, C. R., \& Ember, M. (1996). Anthropology. New Jersey. Upper Saddle River, NJ: Prentice Hall, 1996:125

Fischer, G. (2014). Learning, social creativity, and cultures of participation. In A. Sannino \& V. Ellis (Eds.). Retrieved from http://13d.cs.colorado.edu/ gerhard/papers/2013/helsinki.pdf, Learning and collective creativity: Activity-theoretical and sociocultural studies (pp. 198-215). New York, NY: Taylor \& Francis/Routledge.

Fischer, G., \& Shipman, F. (2011). An Interdisciplinary Journal on Humans in ICT Environments. Collaborative Design Rationale and Social Creativity in Cultures of Participation. ISSN.: University of Colorado, 7(2), 1795-6889

Furchan (2005). Arief dan Agus Maimun. Yogyakarta, Indonesia: Studi Tokoh: Pustaka Pelajar

Hermantoro, H. (2011). Creative-based tourism: Dari Wisata Rekreatif menuju Wisata Kreatif. Depok, Indonesia: Penerbit Aditri

Jelinčić, D. A., \& Senkić, M. (2017). Creating a heritage tourism experience. The power of the senses. Etnološka Tribina, 47(40), 109-126. doi: 10.15378/1848-9540.2017.40.03

Kementerian kebudayaan dan pariwisata (2010). Pemetaan potensi Pariwisata dalam Mendukung pengembangan Pariwisata berbasis kreativitas (creative-based tourism). Laporan akhir.

Munandar (2009). Kreativitas and Keberbakatan. [Jakarta: Gramedia pustaka utama]

Munandar (2012). Pengembangan kreativitas anak berbakat. Jakarta: Rineka Cipta

Musthofa, B. M., \& Gunawijaya, Jajang (2017). Saung Angklung Udjo: Invensi Tradisi Lokal yang Mendunia. Jurnal Indonesia https://doi/org/10.7454/ai.v38i2.8776, 38(2). doi: 10.7454/ai.v38i2.8776

Neuman, W. L. (2013). Social research method: Qualitative and quantitative approaches p. 45. Boston: Allyn \& Bacon

Owlia, M. S. (2008). Innovation Center: A climate for attracting and developing creativity p. 40. Yazd University, Page (2008). Refereed edition. Editors, IV(1, June)@ asiaentrepreneurshipjournal.com

Reilly, R. (2004). Social creativity, values and shared expertise Thesis Department of Educational and Counselling Psychology McGill University. Montreal.

Richards, G. (2009). Creative tourism and local development. In R. Wurzburger, A. Pattakos \& S. Pratt (Eds.), Creative Tourism: A global conversation (pp. 78-90). Santa Fe: Sunstone Press.

Richards, G. (2011). Creativity and tourism: The state art. Annals of Tourism Research, 38(4), 1225-1253. doi: 10.1016/j.annals.2011.07.008

Richards, G., \& Raymond, C. (2000). Creative tourism. Atlas News, 23, 16-20.

Semiawan, R. C. (2009). Kreativitas Keberbakatan: Mengapa, apa dan bagaimana. Jakarta; PT. Index.

Soemardjan, S. (1983). Kreativitas, Suatu Tinjauan dari Sosiologi. In Sutan Takdir Alisyahbana (Ed.), dalam: Penerbit Dian rakyat. Jakarta: Kreativitas.

Supriadi, D. (1994). Kreativitas kebudayaan dan perkembangan Iptek. Bandung, Indonesia: Alfabeta

UNESCO (2006). Towards sustainable strategies for creative tourism discussion report of the planning meeting for 2008 international conference on creative tourism, Santa Fe, New Mexico, USA October 25-27.

Watson, E. (2007). Who or what creates? A conceptual framework for social creativity. Human Resource Development Review. SAGE Publications, 6(4, December), 419-441, doi: 10.1177/1534484307308255.

http://bandung.bisnis.com/read/20120317/12/157872/ seru-ramai-ramai-bermain -angklung-dengan-iphone-di-saung-udjo, Sabtu, 17/03/2012 13:24 WIB

http://indonesiatouristnews.com/ Global Tourism Continues to Grow 2018, Total 1.322 Billion Tourists Throughout the Year 2017/ Date accessed 23 April 2018 